\title{
Valtioneuvoston periaatepäätös ammatillisen aikuiskoulutuksen rahoittamisen suunnitteluperiaatteista
}

\section{Taustaa}

Tilastokeskuksen selvityksen mukaan vuosikymmenen taitteessa 1,5 vuoden aikana noin 700000 henkilöä osallistui ammatilliseen aikuiskoulutukseen.

Opetushallinnon alaisuudessa tähän koulutukseen osallistuu vuosittain yli 250000 henkilöä. Koulutuksen järjestäjinä toimivat $\mathrm{mm}$.

— ammatilliset kurssikeskukset (työllisyyskoulutus ja muu kurssitoiminta),

- ammatilliset oppilaitokset (iltalinjat, jatkolinjat ja erikoisluokat, kurssitoiminta, työllisyyskoulutus, yksityisoppilaat),

- teollisuuden ammattikoulut, ammattiopistot ja liikealan erikoisoppilaitokset (jatkokoulutus ja kurssitoiminta), sekä

- korkeakoulujen täydennyskoulutuskeskukset ja kesäyliopistot (avoin korkeakouluopetus ja kurssitoiminta).

\section{Päätöksen tavoite}

Periaatepäätös määrittää valtion, kuntien ja työnantajien vastuun ammatillisen aikuiskoulutuksen tarjonnan rahoittamisessa ja yhtenäistää rahoituksen perusteita.

Lisäksi periaatepäätöksellä määritetään aikuisopiskelijain toimeentuloturvan kehittäminen niin, että he pystyisivät entistä paremmin ja monipuolisimmin käyttämään hyväkseen lisääntyviä koulutusmahdollisuuksia.

\section{Eri osapuolten vastuualueet}

Opetushallinnon vastuulle jää omaehtoisesti koulutukseen hakeutuville suunnatun koulutustarjonnan rahoittaminen ja heidän toimeentuloturvansa järjestäminen, työllisyyskoulutuksessa koulutusta järjestävien oppilaitosten perusresurssointi sekä sellaisten edellytysten luominen oppilaitoksille ja korkeakouluille, että nämä voivat tarjota riittävästi ja riittävän tasokkaita henkilöstökoulutuspalveluja.

Kuntien vastuulle jää osallistuminen ammatillisen perus- ja jatkokoulutuksen tarjonnan rahoittamiseen sekä oman henkilöstönsä koulutuksen rahoitus.

Työnantajan vastuulle jää oman henkilöstökoulutuksensa rahoittaminen. Opetushallinto tukee kuitenkin edelleen pienyritysten henkilöstökoulutusta ja teollisuuden ammattikoulujen, ammattiopistojen liikealan erikoissoppilaitosten toimintaa.

Kukin ministeriö vastaa oman sektorinsa kehittämiseen liittyvän aikuiskoulutuksen rahoittamisesta. Tämän periaatteen mukaisesti työllisyyskoulutus järjestetään siten, että opetushallinto vastaa oppilaitosten perusresurssoinnista ja työvoimahallinto ostaa ko. koulutuksen ammatillisilta kurssikeskuksilta, oppilaitoksilta, korkeakouluilta tai muilta koulutuksen järjestäjiltä. Vastaavasti esimerkiksi terveydenhuoltoalan lakisääteisen täydennyskoulutuksen rahoituksesta vastaa työnantaja ja tähän tarkoitukseen tuleva valtiojirahoitus otettaisiin sosiaali- ja terveysministeriön pääluokkaan valtion tulo- ja menoarviossa.

\section{Aikuisopiskelijan toimeentuloturva}

Opintotukilain muuttamisesta annetun lain (95/87) mukaan aikuisopintorahaa koskeva kokeilu järjestetään vuosina 1987-1990. Aikuisopintorahana voidaan suorittaa ansiotason mukaan määräytyvää ansionmenetyskorvausta muun opintotuen lisäksi.

Periaatepäätöksen tavoitteeksi on asetettu työttömyyden perusteella määräytyvä perustoimeentuloturva kaikille 30-vuotta täyttäneille opiskelijoille. Tämä tulos saavutettaneen kokeiluna jo niiden opiskelijoiden osalta, joiden tulojen perusteella määräyよyvä aikuisopintoraha muodostuu keskimääristä suuremmaksi.

Aikuisopintorahakokeilun yhteydessä päätetään myöhemmin milioin perustoimeentuloturva aikuisopiskelijoille turvataan. 


\section{Valtioneuvoston periaatepäätös}

Valtioneuvosto on, asian oltua 26.2.1987 valmistavasti käsiteltävänä valtioneuvoston rahaasiainvaliokunnassa, opetusministeriön esittelystä päättänyt, että ammatillisen aikuiskoulutuksen rahoitusjärjestelmän uudistamista suunnitellaan seuraavien periaatteiden mukaisesti.

\section{Yleistä}

1. Periaatepäätöksellä pyritään tavoitteellisesti selkiyttämään eri osapuolten vastuuta ammatillisen aikuiskoulutuksen tarjonnan rahoittamisessa ja yhtenäistämään rahoituksen perusteita. Tavoitteena on, että monimuotoinen ammatillinen aikuiskoulutus pystyisi joustavasti ja tehokkaasti vastaamaan työelämän nopeasta kehityksestä ja aikuisväestön lisääntyvistä omaehtoisista koulutustarpeista aiheutuvaan koulutuskysyntään. Lisäksi periaatepäätöksellä pyritään aikuisopiskelijain opiskeluaikaisen toimeentuloturvan kehittämiseen niin, että he pystyisivät entistä paremmin ja monipuolisemmin käyttämään hyväkseen lisääntyviä koulutusmahdollisuuksia.

Tähän päätökseen sisältyvät kannanotot on ryhmitelty siten, että ammatilliseen aikuiskoulutukseen, osallistuvat on jaettu omaehtoisesti koulutukseen hakeutuviin, henkilöstökoulutukseen työnantajan määrääminä osallistuviin ja työllisyyskoulutukseen osallistuviin.

\section{Omaehtoisesti koulutukseen ha- keutuvat}

2. Ammatillisten kurssikeskusten ja oppilaitosten järjestämän ammatillisen perus- ja jatkokoulutuksen tarjonta rahoitetaan yhtenäisesti siten kuin ammatillisten oppilaitosten rahoituksesta annetussa laissa (494/83) peruskoulutuksen osalta säädetään. Tästä koulutuksesta aiheutuvien käyttökustannusten rahoitukseen osallistuvat valtio, opiskelijan kotikunta ja kohtuulliseksi katsottavin kustannuksin opiskelija itse.

3. Korkeakoulujen järjestämä aikuisten ammatilliseen peruskoulutukseen rinnastettava koulutus rahoitetaan samalla tavalla kuin muu korkeakoulujen perustutkintoihin johtava koulutus.

4. Ammatillisten kurssikeskusten ja oppilaitosten järjestämän täydennyskoulutuksen tarjonnasta aiheutuvien kustannusten rahoitukseen osallistuvat valtio ja kohtuulliseksi katsottavin kustannuksin opiskelija itse.
5. Korkeakoulujen maksullisena palvelutoimintana järjestämästä täydennyskoulutuksesta opiskelijalle aiheutuvia kustannuksia voidaan alentaa valtion tulo- ja menoarvioon otettavalla määrärahalla.

6. Kohdissa 2-5 tarkoitetun koulutuksen tarjonnan valtionrahoitus säilytetään valtion tulo- ja menoarviossa opetusministeriön pääluokassa.

7. Kohdissa $2-5$ tarkoitettuun koulutukseen osallistuvien opintotukijärjestelmää pyritään kehittämään siten, että 30 vuotta täyttäneille päätoimisesti koulutukseen osallistuville taataan toimeentuloturva, joka on mitoitettu vähintään työttömyyden perusteella maksettavan perusturvan mukaisesti. Aikuisopiskelijain opintotuen tasosta päätetään vuosina 1987-90 toteutettavan aikuisopintorahakokeilun yhteydesä.

8. Ammatillisten oppilaitosten oppilaiden opintososiaalisista eduista annetussa laissa (498/83) tarkoitetut etuudet myönnetään soveltuvin osin ammatillisten kurssikeskusten ja oppilaitosten järjestämään aikuisten ammatilliseen perus- ja jatkokoulutukseen osallistuville.

\section{Henkilöstökoulutukseen työnanta- jan määräämiää osallistuvat}

9. Julkisen hallinnon ja yksityisen sektorin henkilöstökoulutuksesta vastaa työnantaja joko järjestämällä itse tämän koulutuksen tai ostamalla sen muilta koulutuksen järjestäjiltä.

10. Valtio tukee pienyritysten henkilöstökoulutusta valtion tulo- ja menoarviossa opetusministeriön pääluokkaan otettavalla määrärahalla, jolla ammatillinen kurssikeskus, oppilaitos tai korkeakoulu voi alentaa pienyritykselle tästä koulutuksesta aiheutuvia kustannuksia.

11. Valtio osallistuu edelleen ammatillisten erikoisoppilaitosten rahoittamiseen.

12. Henkilöstökoulutukseen työntekijä osallistuu työnantajan määräämänä työ-, virkatai toimiehtosopimuksen mukaisin eduin.

\section{Työllisyyskoulutukseen osallistu- vat}

13. Työllisyyskoulutuksen rahoituksesta vastaa valtio. Tavoitteena on kehittää työllisyyskoulutuksen hallintoa siten, että työvoimahallinto ostaisi työllisyyskoulutuksena järjestettävän ammatillisen perus- ja jatkokoulutuksen ammatillisilta kurssikeskuksilta, oppilaitoksilta ja korkeakouluilta sekä muun koulutuksen edellä mainituilta tai muilta koulutuksen järjestäjiltä valtion 
tulo- ja menoarviossa työvoimaministeriön pääluokkaan osoitettavalla määrärahalla.

14. Työllisyyskoulutukseen osallistuva henkilö saa siihen kuuluvan toimeentuloturvan. Työtön tai välittömästi työttömyysuhan alainen henkilö voi työllisyyskoulutuksen eduilla osallistua muuhunkin koulutukseen.

\section{Kokeilu- ja kehittämistoiminnan ra- hoittaminen}

15. Keskushallinnon hyväksymän kokeilu- ja kehittämistoiminnan suunnittelu- ja seurantakustannuksista vastaa ensisijaisesti valtio. Tässä tarkoituksessa yhdistetään ammattikasvatushallituksessa työllisyyskoulutuksen ja muun aikuiskoulutuksen kehittämisen voimavarat. Korkeakoulujen voimavaroja ammatillisen aikuiskoulutuksen tutkimukseen lisätään.

16. Valtion tulo- ja menoarvioon opetusministeriön pääluokkaan otettavilla määrärahoilla voidaan ammatillisia kurssikeskuksia, oppilaitoksia ja korkeakouluja avustaa maksullisena palvelutoimintana toteutettavan koulutuksen aloittamisessa sekä koulutustarjontansa kehittämisessä, jos yhteiskunnan kannalta tarpeellista koulutusta ei pystytä muutoin riittävästi järjestämään.

\section{Jatkotoimet}

17. Esitettyjen periaatteiden toteuttamiseksi opetusministeriö käynnistää yhteistyössä asianomaisten viranomaisten kanssa ja käyttäen hyväksi alan järjestöjen asiantuntemusta yksityiskohtaisen selvitystyön, jonka yhteydessä valmistellaan tarvittavat säännösmuutokset ja arvioidaan kustannusvaikutukset.

Helsingissä 5 päivänä maaliskuuta 1987

Opetusministeri Pirjo Ala-Kapee

Osastopäällikkö

ylijohtaja Leevi Melametsä 